\title{
Performance of cluster frontline demonstration on productivity and profitability of Blackgram (Vigna mungo) in Raigarh District of Chhattisgarh, India
}

\author{
S. P. Singh* , K. K. Paikra and Chanchala Rani Patel \\ Krishi Vigyan Kendra, Raigarh-496001, Indira Gandhi Krishi Viswavidyalaya, \\ Raipur (C.G.), India \\ *Corresponding author
}

\section{Keywords}

Cluster frontline demonstrations, Improved variety, Blackgram

Article Info

Accepted:

15 May 2018

Available Online:

10 June 2018

\section{A B S T R A C T}

The present study was carried out the evaluating the performance of improved cultivars with scientific package and practices on production, productivity and profitability of blackgram. Cluster frontline demonstrations were conducted during 2016-17 and 2017-18 with evaluation the performance of Indira urd pratham, variety of blackgram in Baramkela and Tamnar blocks of the district and record the feedback information of farmer's. The results revealed that average yield of blackgram under cluster frontline Demonstrations were 11.52 and $11.19 \mathrm{qha}^{-1}$ as compare to 8.75 and $8.45 \mathrm{qha}^{-1}$ recorded in farmer's practice, average yield increase of 31.66 and 32.43 per cent and additional return of 11934.00 and $12986.00 \mathrm{Rsha}^{-1}$, respectively. It was observed that the benefit cost ratio (B: C) of recommended practice (CFLD's) were 3.02 and 2.99 as compared to2.55 and 2.2.48 in farmer's practice during consecutive years of study blocks. The average extension gap $2.75 \mathrm{qha}^{-1}$ and average technology gap $3.64 \mathrm{qha}^{-1}$ was recorded. Therefore, the results clearly indicates that the use of improved varieties and package and practices with scientific intervention under frontline demonstration programme contribute to increase the productivity and profitability of pulses in Chhattisgarh state.

\section{Introduction}

Pulses on account of their vital role in nutritional security and major sources of vegetable proteins. India is the world's largest producer of pulses, it imports a large amount of pulses to meet the growing domestic needs. Thus, India is the largest importer, producer and consumer of pulses. India has to produce not only enough pulses but also remain competitive to protect the indigenous pulse production. Blackgram (Vigna mungo) contain $22-24 \%$ protein, which is almost twice the protein in wheat and thrice that of rice. Pulses provide significant nutritional and health benefits, and are known to reduce several noncommunicable diseases such as colon cancer and cardiovascular diseases (Jukanti et al., 2012). Protein-energy malnutrition as well as micronutrient deficiencies can be addressed by increasing the consumption of pulses which are a rich source of proteins, minerals, iron and fibre. Net daily pulses availability for Indians has increased slightly from $32 \mathrm{~g}$ per capita in 2000 to $37 \mathrm{~g}$ per capita in 2009 . In order for India to meet the 40 grams per day 
per capita requirement of pulses, attention has to be paid to both production and consumption. Thus, a large part of their protein requirement could be met by pulses. Food security stands on the three pillars of availability, access and absorption (nutrition). Pulses availability has also increased 7-8.33 per cent slowly in account of food grain. Availability of pulses has increased in the past decade with the increasing emphasis on development of improved varieties and supportive policies (Source: Directorate of Economics and Statistics, 2016). It produces about $1.5-1.9 \mathrm{mt}$ of black gram annually from about $3.5 \mathrm{~m}$ ha of area, with an average productivity of $600 \mathrm{kgha}^{-1}$. Black gram output accounts for about 10 per cent of India's total pulse production. However, productivity is low due to lack of awareness in farming community regarding improved package and practices of pulse crops. Frontline demonstrations are important dissemination process for transfer of technology and to establish its production potentials on the farmer's field. Pulses can be grown on range of soil and climatic conditions and play important role in crop rotation, mixed and inter-cropping, maintaining soil fertility through nitrogen fixation, release of soilbound phosphorus, and thus contribute significantly to sustainability of the farming systems. It is therefore, necessary to assess the technological gap in production and also to know the problems and constraints in adopting modern blackgram production technologies Islam et al., (2011) and Kumar et al., (2014). Production of major pulses is constrained by both biotic and abiotic stresses. For example, pod borers (Helicoverpa armigera), fusarium wilt, root rots, ascochyta blight and botrytis gray mold are some of the major biotic constraints to increasing the productivity of chickpea. The major constraints to productivity in pigeonpea are biotic stresses such as pod borer, pod fly, Fusarium wilt, and sterility mosaic disease. Similarly, pod borer, aphids, cutworm, powdery mildew, rust and wilt are the major pests and diseases affecting lentil production in India. The richness of legumes in $\mathrm{N}$ and $\mathrm{P}$, makes them attractive for insect pests and diseases (Sinclair and Vadez, 2012). Availability of quality seed of improved varieties and other inputs is one of the major constraints in increasing the production of grain legumes (David et al., 2002). Keeping this in view, the present investigation was undertaken to study the awareness level of farmer's regarding blackgram cultivation, extent of adoption of improved practices, to find out the yield gap in black gram production technology (Devi et al., 2014). Krishi Vigyan Kendra are grass root level organization meant for application of technology through assessment, refinements and dissemination of proven technologies under different micro farming situation in the district (Das, 2007). Cluster frontline demonstrations were conducted on blackgram (Indira urd pratham) during 2016-17 and 2017-18 with disseminate the technology in the district and to establish production potentials on the farmer's field, assessment of adoption and yield gap and record feedback information from farmer's for further improvement in the research and extension programme.

\section{Materials and Methods}

The present study was carried out in the Raigarh district is located on the Northern part of Chhattisgarh state and lies at $21^{\circ} 54^{\prime} \mathrm{N}$ latitude and $83^{\circ} 24^{\prime} \mathrm{E}$ longitude with an altitude of $215 \mathrm{~m}$ above the mean sea level (MSL). Cluster frontline demonstrations were conducted during 2016-17 and 2017-18 with evaluation the performance of Indira urd pratham, variety of blackgram in Baramkela and Tamnar blocks of the district. In this study, 140 farmer's were selected from aforesaid blocks during consecutive years under cluster frontline demonstration of 
blackgram. All the technological intervention were taken as per prescribed package and practices for improved variety of blackgram crop (Table 1). The grain yield, gap analysis, input cost, net return and additional return parameters were recorded (Table 2 and 3).

Assessment of gap in adoption of recommended technology before laying out the cluster frontline demonstrations (CFLD's) through personal discussion with selected farmer's. The awareness programme (training) was organized for selection of farmer's and skilled development about detailed technological intervention with improved package and practice for successful blackgram cultivation. Scientists visited regularly cluster frontline demonstrations fields and farmer's fields also. The feedback information from the farmer's was also recorded for further improvement in research and extension programmes. The extension activities i.e. awareness programme (training), farmer's seminar and field day's were organized at the cluster frontline demonstrations sites.

The basic information were recorded from the farmer's field and analyzed to comparative performance of cluster frontline demonstrations (CFLD's) and farmer's practice. Different parameters were calculated to find out technology gaps (Yadav et al., 2004).

Extension gap $=$ Demonstrated yield- farmer's practice yield

Technology gap $=$ Potential yieldDemonstration yield

Additional return $=$ Demonstration return farmer's practice return

Potential yield-Demonstration yield Technology index= ----------------------- x 100 Potential yield

\section{Results and Discussion}

The improved package and practices is more important with technological intervention for productivity and profitability of pulses. Detailed package and practices with technological intervention for recommended practice (Table 1). It was also observed that farmer's use injudicious and un-recommended insecticides and mostly didn't use fungicides. Similar observations were reported by Singh et al., 2011.

\section{Grain Yield}

The grain yield of demonstrated field's and farmer's practice is presented in table 2. Data revealed that average grain yield of demonstrated field's was higher from farmer's practice in both blocks of Raigarh district.

The results revealed that average grain yield of blackgram under cluster frontline demonstrations were 11.52 and $11.19 \mathrm{qha}^{-1}$ as compare to 8.75 and $8.45 \mathrm{qha}^{-1}$ recorded in farmer's practice and average yield increase of 31.66 and 32.43 per cent, respectively.

The above finding were accordance with Dubey et al., (2010). The extension gap 2.77 and $2.74 \mathrm{qha}^{-1}$, technology gap 3.48 and 3.81 qha $^{-1}$ and technology index 23.20 and 125.40 was recorded (Table 2).

This Extension gap should be assigned to adoption of improved dissemination process in recommended practices which outcome in higher grain yield than the farmer's practice.

The similarly observations were also obtained in blackgram crop by Bairwa et al., (2013) and also Hiremath and Nagaraju (2010). Yield of the recommended practice and potential yield of the crop was compared to estimate the yield gaps which were further categorized in to technology and extension gaps. 
Table.1 Detail of package and practices for blackgram cultivation

\begin{tabular}{|c|c|c|c|}
\hline S. No. & $\begin{array}{l}\text { Technological } \\
\text { intervention }\end{array}$ & Farmer's practice & Recommended Practice (CFLD's) \\
\hline 1. & Variety & $\begin{array}{l}\text { Existing / old recommended } \\
\text { cultivar }\end{array}$ & Indira urd pritham \\
\hline 2. & Seed rate $\left(\mathrm{kgha}^{-1)}\right.$ & 25.0 & 20.0 \\
\hline 3. & Seed treatment. & Not practice. & $\begin{array}{l}\text { Carbendazime } 50 \text { WP @ } 3 \mathrm{~g} \mathrm{~kg}^{-1} \text { seed, } \\
\text { Thiamethoxam } 25 \text { WG } 2 \mathrm{gkg}^{-1}, 5-10 \mathrm{~g} \mathrm{~kg}^{-1} \text { seed } \\
\text { Rhizobium culture and } 5-10 \mathrm{ml} \mathrm{kg}^{-1} \text { seed PSB } \\
\text { culture. }\end{array}$ \\
\hline 4. & Sowing method/Spacing. & $\begin{array}{l}\text { Broadcasting / un uniform plant } \\
\text { population }\end{array}$ & $\begin{array}{l}30 \times 10 \mathrm{~cm} \text {, Sowing with seed cum fertilizer } \\
\text { drill. }\end{array}$ \\
\hline 5. & Time of Sowing & 15 July -15 August & 15July- 30 July \\
\hline 6. & Nutrient management. & $\begin{array}{l}\text { Imbalance use of fertilizers and } \\
20 \mathrm{~kg}^{-1} \text { urea ha } \mathrm{h}^{-1} \text { at and } 50 \mathrm{~kg} \\
\text { DAP at sowing. }\end{array}$ & $\begin{array}{l}\text { Balance fertilization as per soil test values } \\
\text { (STV) } 50 \mathrm{~kg} \mathrm{Urea} \mathrm{ha}^{-1} \text { (in } 2 \text { split application), } \\
310 \mathrm{~kg} \mathrm{SSP} \mathrm{ha}{ }^{-1} \text { and } 30 \mathrm{~kg} \mathrm{MOP} \mathrm{ha}^{-1} \text { at } \\
\text { sowing. }\end{array}$ \\
\hline 7. & Weed management. & No weeding/ manually & Imazethapyr 10SL $75 \mathrm{~g}$ a.i. ha $^{-1}$ at $15-20$ DAS. \\
\hline 8. & $\begin{array}{l}\text { Insect, pest and disease } \\
\text { management. }\end{array}$ & $\begin{array}{l}\text { No/ injudicious use of and } \\
\text { insecticides and fungicides. }\end{array}$ & $\begin{array}{l}\text { Two sprays of Thiamethoxam } 25 \mathrm{WG} @ 0.5 \mathrm{~m} \\
\mathrm{l}^{-1} \text { of water at } 30 \text { and } 45 \text { days for sucking pest } \\
\text { and one spray of Metalaxyl } 35 \% \text { WS } 2 \mathrm{~g}^{-1} \text { of } \\
\text { water for white blister. }\end{array}$ \\
\hline
\end{tabular}

Table.2 Grain yield and gap analysis of cluster frontline demonstrations on blackgram

\begin{tabular}{|c|c|c|c|c|c|c|c|}
\hline \multirow{2}{*}{$\begin{array}{l}\text { Name of } \\
\text { block }\end{array}$} & \multirow{2}{*}{$\begin{array}{l}\text { No. of } \\
\text { demonst } \\
\text { ration }\end{array}$} & \multicolumn{2}{|c|}{ Average yield (ha) } & \multirow{2}{*}{$\begin{array}{l}\text { \% Increase in } \\
\text { Recommended } \\
\text { Practice (RP) }\end{array}$} & \multirow{2}{*}{$\begin{array}{l}\text { Extension } \\
\operatorname{gap}_{\left(\mathbf{q} \mathbf{~ h a}^{-1}\right)}\end{array}$} & \multirow{2}{*}{$\begin{array}{l}\text { Technology } \\
\text { gap }\left(q \mathbf{~ h a}^{-1}\right)\end{array}$} & \multirow{2}{*}{$\begin{array}{l}\text { Technology } \\
\text { index }\end{array}$} \\
\hline & & $\begin{array}{l}\text { Recommended } \\
\text { Practice (RP) }\end{array}$ & $\begin{array}{l}\text { Farmer's } \\
\text { Practice (FP) }\end{array}$ & & & & \\
\hline Baramkela & 76 & 11.52 & 8.75 & 31.66 & 2.77 & 3.48 & 23.20 \\
\hline Tamnar & 64 & 11.19 & 8.45 & 32.43 & 2.74 & 3.81 & 25.40 \\
\hline Average & - & 11.35 & 8.60 & 32.04 & 2.75 & 3.64 & 24.3 \\
\hline
\end{tabular}

Table.3 Economic analysis of the cluster frontline demonstrations on blackgram

\begin{tabular}{|c|c|c|c|c|c|c|c|c|c|}
\hline \multirow{3}{*}{$\begin{array}{l}\text { Name of } \\
\text { block }\end{array}$} & \multicolumn{2}{|c|}{ Total returns(Rs.ha $\left.{ }^{-1}\right)$} & \multicolumn{2}{|c|}{ Input $\operatorname{cost}\left(\right.$ Rs.ha $\left.^{-1}\right)$} & \multicolumn{2}{|c|}{ Net return $\left(\right.$ Rs.ha $\left.^{-1}\right)$} & \multirow{3}{*}{$\begin{array}{l}\text { Additional } \\
\text { return } \\
\left(\text { Rs.ha' }^{-1}\right) \\
\text { FLD's }\end{array}$} & \multirow{2}{*}{\multicolumn{2}{|c|}{ B:C ratio }} \\
\hline & Recommen & Farmer's & Recommen & Farmer's & Recommend & Farmer's & & & \\
\hline & $\begin{array}{l}\text { ded } \\
\text { Practice } \\
\text { (RP) }\end{array}$ & $\begin{array}{l}\text { Practice } \\
(\mathrm{FP})\end{array}$ & $\begin{array}{l}\text { ded } \\
\text { Practice } \\
\text { (RP) }\end{array}$ & $\begin{array}{l}\text { Practice } \\
\text { (FP) }\end{array}$ & $\begin{array}{l}\text { ed } \\
\text { Practice } \\
\text { (RP) }\end{array}$ & $\begin{array}{l}\text { Practice } \\
\text { (FP) }\end{array}$ & & $\begin{array}{l}\text { Recommended } \\
\text { Practice(RP) }\end{array}$ & $\begin{array}{l}\text { Farmer's } \\
\text { Practice } \\
\text { (FP) }\end{array}$ \\
\hline Baramkela & 57600 & 43750 & 19073 & 17157 & 38527 & 26593 & 11934 & 3.02 & 2.55 \\
\hline Tamnar & 60426 & 45630 & 20209 & 18399 & 40217 & 27231 & 12986 & 2.99 & 2.48 \\
\hline Average & 59013 & 44690 & 19641 & 17778 & 39372 & 26912 & 12460 & 3.005 & 2.51 \\
\hline
\end{tabular}

Note: MSP of blackgram @ Rs.5000.00 qt ${ }^{-1}$ in 2016-17 and Rs.5400.00 qt ${ }^{-1}$ in 2017-18.

The observed technology gap may be attributed dissimilarity in soil fertility status, rainfall distribution, disease, insect, pest infestations and weed intensity well as the change in the locations of cluster frontline demonstration sites. The technology index shows the feasibility of the variety at the farmer's field. The lower value of technology index more is the feasibility of technology. This indicates that a gap existed between 
technology evolved and technology adoption at farmer's field. The similar results were also observed by Bairwa et al., (2013), and Dhaka et al., (2010). Hence, it can be concluded from the table 2 that increased yield was due to adoption of improved varieties and conducting demonstration of proven technologies yield potentials of crop can be increased to greater extent. The programme of cluster frontline demonstration could be popularized for other oilseed crops also in order to increase farmer's income and attain self-sufficiency in oilseeds production.

\section{Economics analysis}

Economic performance of blackgram under cluster frontline demonstration were depicted in table 3. The economic analysis results revealed that the blackgram (Indira urd pratham) recorded higher total return from recommended practice (CFLD's) were $60426.00 \mathrm{Rsha}^{-1}$ as compared to 45630.00 Rsha $^{-1}$ farmer's practice of Tamnar block.

The net returns ranged from 38527.00 $40217.00 \mathrm{Rsha}^{-1}$ in recommended practice in comparison to $26593.00-27231.00 \mathrm{Rsha}^{-1}$ in farmer's practice of both blocks. It was economically observed that additional return ranged from 11934.00 - $112986.00 \mathrm{Rsha}^{-1}$ in recommended practice. The benefit cost ratio also recorded higher in recommended practice with 3.02 and 2.99 as compared to 2.55 and 2.48 in farmer's practice.

The higher net returns and $\mathrm{B}: \mathrm{C}$ ratio in black gram demonstration might be due to the higher grain yield and better pricing of the produce in the market. These results in accordance with the findings of Gurumukhi and Mishra (2003) and Dhaka et al., (2010). Recommended practice (CFLD's) proved beneficial in respect of yield and economics of blackgram in consecutive blocks of Raigarh District In Chhattisgarh Plains.
The present study revealed that Indira urd pratham variety of blackgram gave higher yield and net returns in recommended practice (CFLD's) than farmer's practice in all block's Raigarh district. The highest grain yield was attributed to higher potential with improved variety, timely sowing, nutrient management, weed management, insect, pest and disease management in accordance of scientific package and practice. Economic analysis of different parameter's revealed that net return and additional return were recorded highest with recommended practice (CFLD's). The study was concluded that Indira urd pratham in recommended practice proved beneficial in respect of yield and economics of blackgram.

\section{References}

Anonymous (2016). Agricultural statistics at a glance. DAC Government of India. p. 118.

Bairwa, R. K., Verma, S. R., Chayal, K. and Meena, N. L. (2013). Popularization of Improved Black gram Production Technology through Front line demonstration in humid southern plain of Rajasthan, Indian Journal of Extension Education and R.D. 21: 97101.

Das Mamoni, Puzari N N and Ray B K 2010. Impact of training of skill and knowledge development of rural women, Agricultural Extension Review, 1(1): 29-30.

David S, Mukandala L and Mafuru J. 2002. Seed availability, an ignored factor in crop varietal adoption studies: a case study of beans in Tanzania. Journal of Sustainable Agriculture 21, 5-20.

Devi, M. Ganga, Kumar, Ch. Anil and Kumar, D. Srinivas (2017). Impact Analysis of Trainings and Front Line Demonstrations in blackgram (Vigna mungo) Cultivation. J Krishi Vigyan. 6(1): 97-100. 
Dhaka, B.L, Meena, B.S. and Suwalka, R. L. (2010). Popularization of improved maize technology through frontline demonstration in South-eastern Rajasthan. Journal of Agricultural Sciences (1): 39-42.

Dubey S, Tripathi S, Singh P and Sharma R K (2010). Yield gap analysis of black gram production through frontline demonstration. J Prog Agric 1(1): 4244.

Gurumukhi, D. R, and Mishra, S. 2003. Sorghum front line demonstration - A success story. Agriculture Extension Review, 15(4): 22-23.

Hiremath, S.M and Nagaraju, M.V. (2010). Evaluation of on front line demonstrations on the yield of chilli, Karnataka J. Agric. Sci., 23 (2): 341342.

Islam M, Mohanty A K and Kumar S (2011). Correlation growth yield and adoption of urdbean technologies. Indian Res $J$ Ext Edu 11 (2): 20-24.
Jukanti, A, K., Gaur, P.M., Gowda. C.L.L. and Chibbar, R.N. (20120. Nutritional quality and health benefits of chickpea (Cicer arietinum L.): a review. British Journal of Nutrition 108, S11-S26.

Kumar S, Singh R and Singh A (2014). Assessment of gaps in pulse production in Hamipur district of Himachal Pradesh. Indian Res J Ext Edu 14 (2): 20-24.

Sinclair, T.R. and Vadez, V. (2012). The future of grain legumes in cropping systems. Crop \& Pasture Science. http://dx.doi.org/10.1071/ CP12128.

Singh, G., Dhaliwal, N.S., Singh, J. and Sharma, K. (2011). Effect of frontline demonstrations on enhancing productivity of mustard. Asian J Soil Sci 6: 230-33.

Yadav, D.B., Kamboj, B.K. and Garg, R.B. (2004). Increasing the productivity and profitability of sunflower through frontline demonstrations in irrigated agro-ecosystem of eastern Haryana. $J$ Agron 20: 33-35.

\section{How to cite this article:}

Singh S. P., K. K. Paikra and Chanchala Rani Patel. 2018. Performance of cluster frontline demonstration on productivity and profitability of Blackgram (Vigna mungo) in Raigarh District of Chhattisgarh, India. Int.J.Curr.Microbiol.App.Sci. 7(06): 1325-1330 doi: https://doi.org/10.20546/ijcmas.2018.706.155 